$\underline{\text { Research Article }}$

\title{
Prevalence, behavioral and socioeconomic factors associated with human immunodeficiency virus in Ghana: a population-based cross-sectional study
}

\author{
Djibril M Ba ${ }^{1}$, Paddy Ssentongo ${ }^{2}$, Kristin K Sznajder ${ }^{1}$ \\ 1 Department of Public Health Sciences, Penn State College of Medicine, Hershey, Pennsylvania, USA, ${ }^{2}$ Department of Public Health Sciences, Penn \\ State College of Medicine, Hershey, Pennsylvania, USA; Center for Neural Engineering, Department of Engineering, Science and Mechanics, The \\ Pennsylvania State University, University Park, Pennsylvania, USA \\ Keywords: ghana, hiv, global health \\ https://doi.org/10.29392/joghr.3.e2019092
}

Journal of Global Health Reports

Vol. 3, 2019

\section{Background}

Human immunodeficiency virus (HIV) is a serious public health problem and cause of death in many parts of Africa, including Ghana. Ghana has one of the highest rates of HIV in West Africa, yet factors associated with the prevalence of HIV infection are not well characterized.

\section{Objectives}

This study aimed to assess HIV prevalence and associated knowledge, attitudes, and behavioral factors among men and women in Ghana.

\section{Methods}

This a population-based cross-sectional study of 4,687 women between the ages of 15-49 years and 4,161 men between the ages of 15-59 years who participated in the Ghana Demographic and Health Surveys 2014 (GDHS-2014). The outcome variable was HIV status assessed through a blood test. Multivariable logistic regression was used to identify potential factors that were associated with HIV.

\section{Results}

The overall prevalence of HIV in this study was $2 \%$. Among women, the prevalence was $2.5 \%$, and among men the prevalence was $1.1 \%$. Increasing age was positively associated with the likelihood of HIV infection. Women between the ages of 35-49 years (adjusted odds ratio, $\mathrm{aOR}=3.51,95 \%$ confidence interval, $\mathrm{CI}=1.65-7.47$ ) and men between the ages of 35-49 years $(\mathrm{aOR}=7.07,95 \% \mathrm{CI}=1.48-33.80)$ were at a higher odds for HIV compared with women and men between the ages 15-24 years. Widowed, divorced, or separated women and men were more likely to test positive for HIV infection (aOR=1.78, 95\% $\mathrm{CI}=1.00-3.15)$ and $(\mathrm{aOR}=2.95,95 \% \mathrm{CI}=1.26-6.91)$ when compared with never married women and men, respectively.

\section{Conclusions}

In Ghana, the prevalence of HIV among women was approximately twice that of men. Factors such as increasing age, marital status, ever been tested for HIV, having one sex partner, and religion were significantly and independently associated with higher odds of HIV infection in Ghana.

According to the Joint United Nations Programme on HIV/AIDS (UNAIDS), Human immunodeficiency virus (HIV) is a pandemic with a worldwide prevalence of 37 million people as of $2016 .{ }^{1}$ Sub-Saharan Africa (SSA) is the most affected region accounting for approximately $70 \%$ of the people living with HIV worldwide. In Ghana, the estimated number of adults aged 15 and over living with HIV was 310,000 and was higher in women $(200,000)$ than in men $(100,000)$ in $2018 .^{2}$ The first HIV cases in Ghana were diag- nosed in $1986^{3}$; however, efforts to track prevalence did not begin until 1990 . Since then, multiple research programs have been put in place to estimate and reduce the prevalence of HIV. Ghana has made significant progress in the fight against HIV by putting in place the Ghana Acquired immunodeficiency syndrome (AIDS) Commission (GAC), a multi-sectoral organization under the office of the president that is responsible for the management and coordination of the national response to the HIV epidemic in Ghana. 
Over half of Ghanaians living with HIV are between the ages of $24-39 .{ }^{4}$ Heterosexual intercourse is the primary mode of HIV infection in Ghana and accounts for 75 to $80 \%$ of all HIV cases. ${ }^{5}$ Additional modes of transmission include vertical transmission from mother-to-child and blood transfusions, which account for $20 \%$ of HIV infections in Ghana. ${ }^{6}$ The most predominant HIV infectious agent in Ghana is HIV-1, accounting for $94 \%$ of all HIV cases. ${ }^{7}$ The incidence of HIV per 1000 population among adults between the ages of $15-49$ was 1.10 in $2018 .^{2}$ The estimation of the current HIV prevalence and delineating factors that are associated with HIV infection is vital for the planning and implementation of HIV prevention, education, treatment, and support programs.

The objective of this study was to assess HIV prevalence and HIV related knowledge, attitudes, and behaviors factors associated factors with HIV infection among women and men aged 15-49 years and 15-59 years, respectively, using Ghana demographics and health survey 2014 (GDHS-2014). To our knowledge, this is the first study to explore factors associated with HIV infection in Ghana using the most recent GDHS with a large sample size.

\section{MATERIALS AND METHODS}

\section{DATA SOURCE AND STUDY DESIGN}

This is a cross-sectional population-based study using the GDHS-2014 data. ${ }^{8}$ The GDHS-2014 is a nationally representative survey that uses a multistage and stratified design to collect information on population health, HIV, malaria, and nutrition. ${ }^{9}$ The individual women's and men's data from the GDHS-2014 dataset were used in this analysis. Survey questions analyzed in this study included demographics, socioeconomic status, sexual behaviors, knowledge of HIV, prior HIV testing, and HIV status. The questionnaire was based on Demographic and Health Surveys (DHS) guidelines and adapted to reflect the current health issues that affect the Ghanaian population.

\section{HIV TESTING AND PROCEDURE}

Since 2001, the DHS has conducted population-based HIV testing across developing countries to estimate the prevalence of HIV. ${ }^{10}$ Furthermore, DHS offers nationally representative estimates of HIV prevalence rates across countries. The protocol of DHS HIV testing includes anonymous testing that is voluntary by accepting informed consent or refusing to take the test. ${ }^{11}$ Before testing, each respondent receives free educational materials about HIV, free counseling, and information on where to take an HIV test. After consent, the investigators take a blood sample to be tested using a barcode. To ensure confidentiality, the HIV test results data were linked to individual surveys with no personal identifiers, which helps to perform in-depth statistical analysis of the socio-demographic, knowledge of HIV, and behavioral factors associated with HIV infection.

\section{STUDY POPULATION}

Analyses were restricted to 4,161 male respondents aged $15-59$ years and 4,687 female respondents aged $15-49$ years who had complete HIV test results data in the 2014 GDHS. There were a total of 119 HIV cases among women and 45 HIV cases among men.

\section{ETHICAL CONSIDERATIONS}

Procedures and questionnaires for standard DHS surveys have been reviewed and approved by the ICF Institutional Review Board (IRB) and the IRBs of the host countries. Each participant voluntarily provided written informed consent before the beginning of each survey and blood draw. These ethical issues were handled by those who conducted the surveys and not the current authors of the manuscript.

\section{ASSESSMENT OF HIV STATUS (OUTCOME)}

The primary outcome variable for this study was HIV status, a binary variable with one representing a positive HIV test result and zero representing a negative HIV test result. Blood spots were collected on filter paper from a finger prick of each respondent and transported to a laboratory for further testing. An initial ELISA test is usually conducted at the laboratory, and then retesting of all positive tests and 5-10 percent of the negative tests with a second ELISA test. ${ }^{10}$

\section{ASSESSMENT OF FACTORS ASSOCIATED WITH HIV STATUS}

We explored the following potential determinants of HIV infection: age, education, religion, marital status, wealth index, employment status, place of residence (urban/rural), related behavior, and knowledge of HIV prevention. ${ }^{12}$ According to previously published research studies, we recategorized the wealth index from five quintiles into three categories by combining poorest and poorer into one category (called "poor"); middle wealth level into the second category (called "middle"); and richer and richest into the third category (called "rich"). ${ }^{13-15}$ The age of the respondent at the time of the DHS interview was originally measured as a continuous variable and was categorized into four categories (15-24, 25-34, and 35-49, 50-59 years).

\section{STATISTICAL ANALYSIS}

To investigate factors associated with HIV infection, we used descriptive, bivariate, and multivariable logistic regression statistical methods. In the descriptive analysis, sociodemographic factors, HIV-related behaviors, and knowledge of HIV prevention were stratified by HIV status. The descriptive results are presented as proportions, and a chisquared test was conducted to test the association with HIV status. Multivariable logistic regression was used to investigate the independent factors associated with HIV infection. The bivariate and multivariable logistic regression results are presented as crude (OR) and adjusted odds ratios (aOR), respectively, with 95\% confidence intervals and p-values. We employed generalized additive mixed-effects models to create a spatial predictive probability of being HIV positive. The results were reported on an approximately $11 \mathrm{~km}$ by 11 $\mathrm{km}$ regular grid covering the entire country of Ghana. All statistical analyses were conducted using SAS version 9.44 
(SAS Institute) and R statistical software. We assessed statistical significance at $P<0.05$.

\section{RESULTS \\ DESCRIPTIVE ANALYSIS OF THE SOCIO-DEMOGRAPHIC CHARACTERISTICS OF THE SAMPLE POPULATION}

In Table 1, we report the findings of the socio-demographic characteristics of the survey respondents. Among 4,161 male respondents, 45 had a positive HIV test, and among 4,687 female respondents, 119 had a positive HIV test. The overall prevalence of HIV in our study sample was $2 \%$ and was higher in women (2.5\%) than in men (1.1\%). There was a statistically significant difference in the HIV status among different age groups for both women and men $(P<0.001)$. Among women, the proportion of HIV was higher between the ages of 35-49 (52\%), and men (53\%) compared those between the ages of 15-24. Women living in urban areas were more likely to be infected with HIV (58\%) compared to those living in rural areas (42\%) $(P=0.041)$. Furthermore, the proportion of HIV was higher among women who were not sexually active in the last four weeks (52\%) compared to those who never had sex (2\%) and those sexually active in the last four weeks (46\%) $(P=0.001)$. However, the proportion of HIV was higher among men who reported being sexually active in the last four weeks (58\%) compared to those who never had sex (2\%) and those not active in last four weeks (40\%) $(P=0.009)$.

\section{HIV-RELATED KNOWLEDGE AND BEHAVIORS}

The distributions of HIV knowledge and related behaviors among the survey respondents are summarized in Table 2. Men who did not have a sexually transmitted infection (STI) in the last 12 months had the highest proportion of HIV (89\%) $(P=0.036)$. Respondent women and men who knew how to get condoms were more likely to be HIV positive, with $70 \%(P=0.010)$ and $100 \%(P=0.045)$, respectively. Among women, $74 \%$ of respondents with knowledge of HIV where to get a female condom were HIV positive $(P=0.015)$.

\section{UNADJUSTED LOGISTIC REGRESSION ANALYSIS OF HIV ASSOCIATIONS}

From the bivariate analysis (Table 3), factors that were associated with the odds of having HIV included: age, marital status, wealth status, living in the rural areas (only among women) and currently employed (only among men), religion (only among women), recent sexual activity, and that the respondent knows a place to get an HIV test.

\section{INDEPENDENT FACTORS ASSOCIATED WITH HIV INFECTION}

The results of the multivariable logistic regression model are summarized in Table 4. Increasing age was positively and independently associated with the prevalence of HIV infection in both women and men. The adjusted odds ratio (aOR) of HIV infection was twice as high among women between the ages of 25-34 years (aOR=2.39, 95\% $\mathrm{CI}=1.18-4.88$ ), and over three times as high among women

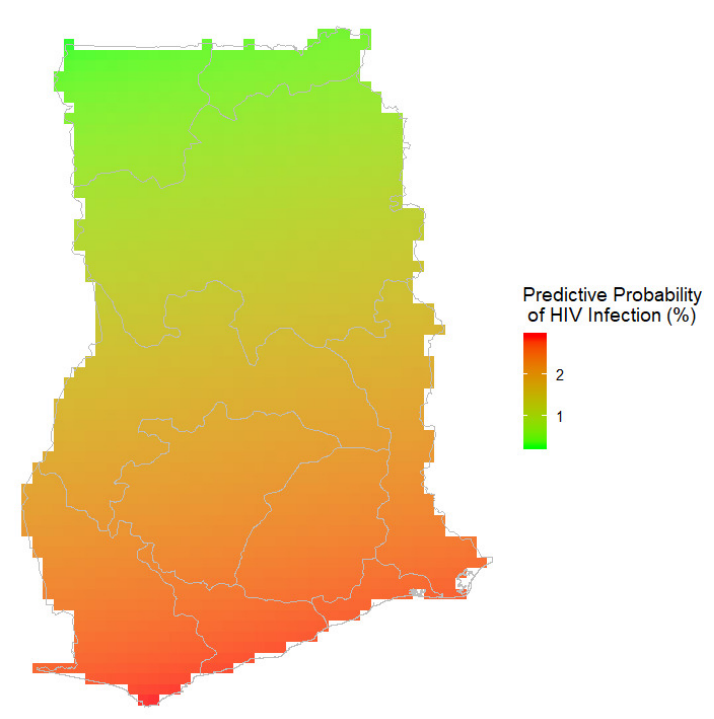

\section{Figure 1. Predicted HIV risk maps for Ghana}

The color scale ranges from green to red, with red areas being high-risk areas and green areas being low-risk areas. The results are reported on approximately $11 \mathrm{~km}$ by $11 \mathrm{~km}$ regular grid covering the entire country of Ghana. Greater Accra, Ashanti, Western, Central, Volta, and Eastern regions have the highest probability of HIV infections.

aged 35-49 years $(\mathrm{aOR}=3.51,95 \% \mathrm{CI}=1.65-7.47)$ compared to women between the ages of 15-24 years. Similarly, men aged 35-49 years were seven times more likely to be infected with HIV infection (aOR=7.07, 95\% CI=1.48-33.80) compared to men between the ages of 15-24 years. Widowed, divorced, or separated women and men were more likely to be infected with HIV (aOR=1.78, 95\% CI=1.00-3.15) and (aOR=2.95, 95\% CI=1.26-6.91) respectively. Men who have ever been tested for HIV were more likely to have an HIV infection (aOR=2.07, 95\% CI=1.08-3.99) as compared to those who had never been tested for HIV. Women who reported currently having one sexual partner were three times more likely to be HIV positive ( $\mathrm{aOR}=3.44,95 \% \mathrm{CI}=1.07-11.10$ ) compared to those that did not report having only one sexual partner. Being a Muslim woman was a protective factor from HIV infection compared with being a Catholic woman (aOR=0.34, 95\% CI=0.12-0.97), However, being a female Protestant did not have a significant association with HIV compared to Muslim and Catholic women.

\section{MAPPING OF HIV RISK}

In Figure 1, we report the predictive map of HIV risk for Ghana. The results are reported on approximately $11 \mathrm{~km}$ by $11 \mathrm{~km}$ regular grid covering the entire country of Ghana. Greater Accra, Western, Central, Volta, and Eastern regions have the highest probability of HIV infections. 
Table 1. Socio-demographic characteristics of the survey respondents

\begin{tabular}{|c|c|c|c|c|c|c|}
\hline & & $\begin{array}{l}\text { Women (No., } \\
\% \text { ) }\end{array}$ & & $\begin{array}{l}\text { Men (No., } \\
\%)\end{array}$ & & \\
\hline & $\begin{array}{c}\text { HIV } \\
\text { negative }\end{array}$ & HIV positive & & $\begin{array}{c}\text { HIV } \\
\text { Negative }\end{array}$ & $\begin{array}{c}\text { HIV } \\
\text { Positive }\end{array}$ & \\
\hline Variables & $(\mathrm{N}=4568)$ & $(\mathrm{N}=119)$ & $P$-value & $(\mathrm{N}=4116)$ & $(\mathrm{N}=45)$ & $P$-value \\
\hline Age: & & & $<0.001$ & & & $<0.001$ \\
\hline $15-24$ & $\begin{array}{c}1657 \\
(36.27)\end{array}$ & $18(15.13)$ & & $\begin{array}{c}1458 \\
(35.42)\end{array}$ & $3(6.67)$ & \\
\hline $25-34$ & $\begin{array}{c}1385 \\
(30.32)\end{array}$ & 39 (32.77) & & $993(24.13)$ & $11(24.44)$ & \\
\hline $35-49$ & $\begin{array}{c}1526 \\
(33.41)\end{array}$ & $62(52.10)$ & & $\begin{array}{c}1167 \\
(28.35)\end{array}$ & $24(53.33)$ & \\
\hline $50-59$ & & & & $498(12.1)$ & $7(15.56)$ & \\
\hline Marital status: & & & $<0.001$ & & & $<0.001$ \\
\hline Never married & $\begin{array}{c}1470 \\
(32.18)\end{array}$ & $23(19.33)$ & & $\begin{array}{c}1781 \\
(43.27)\end{array}$ & $8(17.78)$ & \\
\hline Married/Living with partner & $\begin{array}{c}2669 \\
(58.43)\end{array}$ & $70(58.82)$ & & $\begin{array}{l}2140 \\
(51.99)\end{array}$ & $29(64.44)$ & \\
\hline $\begin{array}{l}\text { Widowed/Divorced/ } \\
\text { Separated }\end{array}$ & $429(9.39)$ & $26(21.85)$ & & $195(4.74)$ & $8(17.78)$ & \\
\hline Number of union: & & & $<0.001$ & & & $<0.001$ \\
\hline No & $\begin{array}{c}1470 \\
(77.41)\end{array}$ & $23(46.94)$ & & $\begin{array}{c}1781 \\
(90.13)\end{array}$ & $8(50)$ & \\
\hline Yes & $429(22.59)$ & $26(53.06)$ & & $195(9.87)$ & $8(50)$ & \\
\hline Type of place of residence: & & & 0.041 & & & 0.056 \\
\hline Urban & $\begin{array}{c}2214 \\
(48.47)\end{array}$ & $69(57.98)$ & & $\begin{array}{c}1881 \\
(45.70)\end{array}$ & $27(60)$ & \\
\hline Rural & $\begin{array}{c}2354 \\
(51.53)\end{array}$ & $50(42.02)$ & & $2235(54.3)$ & $18(40)$ & \\
\hline Educational level: & & & 0.418 & & & 0.472 \\
\hline No education & $\begin{array}{l}1130 \\
(24.74)\end{array}$ & $29(24.37)$ & & $631(15.33)$ & $4(8.89)$ & \\
\hline Primary & $860(18.83)$ & $28(23.53)$ & & $651(15.82)$ & $7(15.56)$ & \\
\hline Secondary/Higher & $\begin{array}{c}2578 \\
(56.44)\end{array}$ & $62(52.1)$ & & $\begin{array}{c}2834 \\
(68.85)\end{array}$ & $34(75.56)$ & \\
\hline Wealth index: & & & 0.026 & & & 0.099 \\
\hline Poor & $2028(44.4)$ & 38 (31.93) & & $\begin{array}{c}1930 \\
(46.89)\end{array}$ & 15 (33.33) & \\
\hline Middle & $942(20.62)$ & $30(25.21)$ & & $749(18.2)$ & $13(28.89)$ & \\
\hline Rich & $\begin{array}{c}1598 \\
(34.98) \\
\end{array}$ & $51(42.86)$ & & $\begin{array}{c}1437 \\
(34.91) \\
\end{array}$ & $17(37.78)$ & \\
\hline Religion: & & & 0.004 & & & 0.536 \\
\hline Catholic & $652(14.28)$ & $16(13.45)$ & & $583(14.16)$ & $6(13.33)$ & \\
\hline Protestant & $\begin{array}{c}2793 \\
(61.16)\end{array}$ & $90(75.63)$ & & $\begin{array}{c}2158 \\
(52.43)\end{array}$ & $28(62.22)$ & \\
\hline Muslim & $888(19.44)$ & $9(7.56)$ & & $872(21.19)$ & $6(13.33)$ & \\
\hline Traditional/no religion & $234(5.12)$ & $4(3.36)$ & & $503(12.22)$ & $5(11.11)$ & \\
\hline Employment status: & & & 0.160 & & & 0.025 \\
\hline Not working & $\begin{array}{c}1263 \\
(27.67)\end{array}$ & $26(21.85)$ & & $700(17.01)$ & $2(4.44)$ & \\
\hline Currently working & $\begin{array}{c}3301 \\
(72.33)\end{array}$ & $93(78.15)$ & & $\begin{array}{c}3416 \\
(82.99)\end{array}$ & $43(95.56)$ & \\
\hline Recent sexual activity: & & & 0.001 & & & 0.009 \\
\hline
\end{tabular}




\begin{tabular}{|c|c|c|c|c|c|}
\hline & & $\begin{array}{c}\text { Women (No., } \\
\% \text { ) }\end{array}$ & $\begin{array}{l}\text { Men (No., } \\
\% \text { ) }\end{array}$ & & \\
\hline Never had sex & $602(13.18)$ & $2(1.68)$ & $856(20.8)$ & $1(2.22)$ & \\
\hline Active in last 4 weeks & $\begin{array}{c}1933 \\
(42.33)\end{array}$ & $55(46.22)$ & $\begin{array}{c}1889 \\
(45.91)\end{array}$ & $26(57.78)$ & \\
\hline Not active in last 4 weeks & $\begin{array}{c}2032 \\
(44.49)\end{array}$ & $62(52.1)$ & $\begin{array}{c}1370 \\
(33.29)\end{array}$ & $18(40)$ & \\
\hline Number of wives/partners: & & & & & 0.191 \\
\hline No wives/partners & - & - & $\begin{array}{c}1976 \\
(48.01)\end{array}$ & $16(35.56)$ & \\
\hline One & - & - & $\begin{array}{c}1898 \\
(46.11)\end{array}$ & $27(60)$ & \\
\hline More than one & - & - & $242(5.88)$ & $2(4.44)$ & \\
\hline
\end{tabular}

- not applicable

-Entire sample for each category (the total number for each variable may not sum to the total sample size due to missing values)

\section{DISCUSSION}

This study examined the prevalence and associated factors of HIV infection in Ghana using individual-level data collected in a recent nationally representative GDHS-2014 survey that included HIV testing of women and men. The study found a prevalence of HIV among women approximately twice that of men. The multivariable analysis found a significant positive association between HIV serostatus and age, marital status, ever been tested for HIV, having one sex partner, and religion. There were regional differences in HIV infections. Greater Accra, Western, Central, Ashanti, Volta, and Eastern regions have the highest probability of HIV infections. The findings from this study corroborate with a previous study that looked at the association between exposures such as sociodemographic factors and the risk of getting HIV in SSA. ${ }^{16}$ According to the WHO, approximately three million adults aged $\geqslant 50$ years are living with HIV in SSA and account for $14.3 \%$ of all HIV positive adults. ${ }^{17}$ This study sheds light on the dynamics of HIV infection rates across age groups and gender and could provide evidence for gender and age-specific HIV infection and co-morbidity intervention and treatment programs instead of "one size fits all" prevention strategies.

This study found that testing positive for HIV was associated with having been tested for HIV in the previous year. While testing would not necessarily lead to HIV infection, an understanding of this association would have essential effects on possible HIV intervention efforts to target high-risk populations. Perhaps current testing efforts are reaching populations that need it. Marital status plays a significant role in the prevention of HIV infection, especially in countries where polygamous marriage is allowed. Widowed, divorced, or separated women and men were found to have a higher likelihood of HIV infection. The positive association between marital status and HIV infection found in this study was not surprising. This finding is consistent with previous studies and may illustrate important family dynamics related to HIV infection, including becoming a widow(er) due to a spouse dying of AIDS or possible divorce or separation as a result of HIV infection. ${ }^{18-22}$ HIV infection may spread through new sexual relationships after a spouse dies. In SSA, high-risk practices such as wife inheritance and ritual cleansing, in which a widow is expected to either marry or have sex with relatives of the deceased husband, can increase women's exposure to the HIV virus. ${ }^{17}$ Furthermore, previous studies also found that married individuals are less likely to use condoms compared to single individuals. ${ }^{23,24}$ Lastly, previous studies have also found a higher rate of male infidelity in marriage in Southern Africa, which can cause greater levels of sero-discordancy. ${ }^{25-28}$ The association between HIV and higher socioeconomic status from the bivariate analysis was not surprising and could be, in part, explained by the higher sexual bargaining power of the wealthy and their association with diverse sexual networks. According to previous studies, people with higher socioeconomic status in developing countries tend to have a higher rate of sequential partners, which increased their susceptibility risk of becoming infected with HIV. ${ }^{29,30}$ Positive associations between HIV infection and higher SES have been observed in other countries in SSA. ${ }^{31-34}$

Our findings suggest that the Muslim religion is a protective factor against HIV infection in Ghana. This finding corroborates with a previous study that also found a significant association between religious affiliation and knowledge of HIV in Ghana. ${ }^{35}$ However, according to the authors, religious affiliation was not found to be associated with changes in specific protective behavior, particularly the use of condoms. ${ }^{35}$ Some studies have attributed the reduced rates of HIV infection in Muslim men due to the protective effect of circumcision, which is practiced and required by the Muslim religion. ${ }^{36}$ However, the explanation of the lower risk of HIV rates in Muslim women is not well understood. ${ }^{37}$ Our study findings also suggest increasing age to be positively associated with a higher odds of HIV infection. Although it is not possible to know precisely when the infection of HIV occurred in this study due to its cross-sectional nature, this finding could be explained by increased unprotected sexual behaviors among older adults, such as having multiple sexual partners and the lack of consistent condom use during sex. ${ }^{38}$ It is also possible that women who are approaching menopause may not have the motivation to use condoms frequently to protect themselves, 
Table 2. Knowledge and behaviors of HIV prevention

\begin{tabular}{|c|c|c|c|c|c|c|}
\hline & & $\begin{array}{l}\text { Women } \\
\text { (No.\%) }\end{array}$ & & $\begin{array}{l}\text { Men (No., } \\
\% \text { ) }\end{array}$ & & \\
\hline & $\begin{array}{l}\text { HIV } \\
\text { Negative }\end{array}$ & $\begin{array}{l}\text { HIV } \\
\text { Positive }\end{array}$ & & $\begin{array}{c}\text { HIV } \\
\text { Negative }\end{array}$ & $\begin{array}{c}\text { HIV } \\
\text { Positive }\end{array}$ & \\
\hline Variables & $(\mathrm{N}=4568)$ & $(\mathrm{N}=119)$ & $P$-Value & $(\mathrm{N}=4116)$ & $(\mathrm{N}=45)$ & $P$-Value \\
\hline Ever heard of an STI & & & 0.373 & & & 0.431 \\
\hline No & $119(2.61)$ & $1(0.84)$ & & $56(1.36)$ & 0 & \\
\hline Yes & 4449(97.39) & $118(99.16)$ & & $\begin{array}{c}4060 \\
(98.64)\end{array}$ & $45(100)$ & \\
\hline Ever heard of HIV/AIDS & & & 0.265 & & & 0.385 \\
\hline No & $136(2.98)$ & $1(0.84)$ & & $68(1.65)$ & 0 & \\
\hline Yes & $\begin{array}{c}4432 \\
(97.02)\end{array}$ & $118(99.16)$ & & $\begin{array}{c}4048 \\
(98.35)\end{array}$ & $45(100)$ & \\
\hline $\begin{array}{l}\text { Reduce risk of HIV: Always use } \\
\text { condoms }\end{array}$ & & & 0.083 & & & 0.520 \\
\hline No & $\begin{array}{c}1056 \\
(23.83)\end{array}$ & $20(16.95)$ & & $587(14.50)$ & $5(11.11)$ & \\
\hline Yes & $\begin{array}{c}3375 \\
(76.17)\end{array}$ & $98(83.05)$ & & $3461(85.5)$ & $\begin{array}{c}40 \\
(88.89)\end{array}$ & \\
\hline $\begin{array}{l}\text { Condom used with most recent } \\
\text { partner }\end{array}$ & & & 0.535 & & & 0.620 \\
\hline No & $\begin{array}{c}2990 \\
(92.51)\end{array}$ & $79(90.8)$ & & $\begin{array}{c}2401 \\
(83.86)\end{array}$ & $\begin{array}{c}33 \\
(86.84)\end{array}$ & \\
\hline Yes & $242(7.49)$ & $8(9.2)$ & & $462(16.14)$ & $5(13.16)$ & \\
\hline Had any STI last 12 months & & & 0.874 & & & 0.036 \\
\hline No & $\begin{array}{c}4351 \\
(95.27)\end{array}$ & $113(94.96)$ & & $\begin{array}{c}3950 \\
(95.97)\end{array}$ & $\begin{array}{c}40 \\
(88.89)\end{array}$ & \\
\hline Yes & $216(4.73)$ & $6(5.04)$ & & $166(4.03)$ & $5(11.11)$ & \\
\hline Relationship with most recent se & artner & & 0.262 & & & 0.793 \\
\hline Spouse & $\begin{array}{c}1939 \\
(59.99)\end{array}$ & $47(54.02)$ & & $\begin{array}{c}1717 \\
(59.99)\end{array}$ & $\begin{array}{c}22 \\
(57.89)\end{array}$ & \\
\hline Others & $\begin{array}{c}1293 \\
(40.01)\end{array}$ & $40(45.98)$ & & $\begin{array}{c}1145 \\
(40.01)\end{array}$ & $\begin{array}{c}16 \\
(42.11)\end{array}$ & \\
\hline Can get a condom & & & 0.010 & & & 0.045 \\
\hline No & $\begin{array}{c}1337 \\
(42.59)\end{array}$ & $29(29.59)$ & & $318(8.88)$ & 0 & \\
\hline Yes & $\begin{array}{c}1802 \\
(57.41)\end{array}$ & 69 (70.41) & & $\begin{array}{c}3263 \\
(91.12)\end{array}$ & $40(100)$ & \\
\hline $\begin{array}{l}\text { HIV transmitted during } \\
\text { pregnancy }\end{array}$ & & & 0.671 & & & 0.018 \\
\hline No & $\begin{array}{c}1358 \\
(30.64)\end{array}$ & $34(28.81)$ & & $1085(26.8)$ & $5(11.11)$ & \\
\hline Yes & $\begin{array}{c}3074 \\
(69.36)\end{array}$ & 84 (71.19) & & $2963(73.2)$ & $40(88.89)$ & \\
\hline $\begin{array}{l}\text { HIV transmitted during } \\
\text { delivery }\end{array}$ & & & 0.116 & & & 0.604 \\
\hline No & 1390(31.36) & $29(24.58)$ & & $1317(32.53)$ & $13(28.89)$ & \\
\hline Yes & $3042(68.64)$ & $89(75.42)$ & & $2731(67.47)$ & $32(71.11)$ & \\
\hline $\begin{array}{l}\text { HIV transmitted by } \\
\text { breastfeeding }\end{array}$ & & & 0.485 & & & 0.426 \\
\hline No & 905(20.42) & $21(17.8)$ & & $922(22.78)$ & 8(17.78) & \\
\hline Yes & $3527(79.58)$ & $97(82.2)$ & & $3126(77.22)$ & $37(82.22)$ & \\
\hline Ever been tested for HIV & & & 0.006 & & & 0.003 \\
\hline
\end{tabular}




\begin{tabular}{|c|c|c|c|c|c|c|}
\hline & & $\begin{array}{l}\text { Women } \\
\text { (No. \%) }\end{array}$ & & $\begin{array}{l}\text { Men (No., } \\
\text { \%) }\end{array}$ & & \\
\hline No & $2419(52.98)$ & $48(40.34)$ & & $3263(79.28)$ & $25(55.56)$ & \\
\hline Yes & $2147(47.02)$ & $71(59.66)$ & & $853(20.72)$ & $20(44.44)$ & \\
\hline Know a place to get HIV test & & & 0.008 & & & 0.021 \\
\hline No & $953(21.51)$ & $11(9.32)$ & & 933(23.05) & $4(8.89)$ & \\
\hline Yes & $3478(78.49)$ & 107(90.68) & & $3115(76.95)$ & 41(91.11) & \\
\hline $\begin{array}{l}\text { Paid for sex in the last } 12 \\
\text { months }\end{array}$ & & & - & & & 0.269 \\
\hline No & - & - & & $\begin{array}{c}3186 \\
(97.73)\end{array}$ & $42(95.45)$ & \\
\hline Yes & - & - & & $74(2.27)$ & $2(4.55)$ & \\
\hline Can get a female condom & & & 0.015 & & & 0.134 \\
\hline No & $986(38.79)$ & $21(25.61)$ & & $514(18.95)$ & $3(8.82)$ & \\
\hline Yes & $\begin{array}{c}1556 \\
(61.21)\end{array}$ & $61(74.39)$ & & $\begin{array}{c}2199 \\
(81.05)\end{array}$ & $31(91.18)$ & \\
\hline $\begin{array}{l}\text { Received result from last HIV } \\
\text { test }\end{array}$ & & & 0.202 & & & 0.725 \\
\hline No & $275(12.84)$ & $5(7.04)$ & & $103(12.1)$ & $3(15)$ & \\
\hline Yes & $\begin{array}{c}1867 \\
(87.16)\end{array}$ & $66(92.96)$ & & $748(87.9)$ & $17(85)$ & \\
\hline \multicolumn{2}{|c|}{ Reduce risk getting HIV: have sex with 1 partner } & & 0.014 & & & 0.154 \\
\hline No & $613(13.83)$ & $7(5.93)$ & & $331(8.18)$ & $1(2.27)$ & \\
\hline Yes & $\begin{array}{c}3818 \\
(86.17)\end{array}$ & $111(94.07)$ & & $\begin{array}{c}3717 \\
(91.82)\end{array}$ & $\begin{array}{c}43 \\
(97.73) \\
\end{array}$ & \\
\hline Respondent circumcised & & & - & & & 0.255 \\
\hline No & - & - & & $300(7.29)$ & $1(2.22)$ & \\
\hline Yes & - & - & & $\begin{array}{c}3816 \\
(92.71)\end{array}$ & $\begin{array}{c}44 \\
(97.78)\end{array}$ & \\
\hline
\end{tabular}

STI - sexually transmitted infection, - not applicable

Entire sample for each category (the total number for each variable may not sum to the total sample size due to missing values)

which may put them at a higher risk of getting infected with HIV. The higher prevalence with HIV among older women found in this study could reflect infections at a younger age.

This study showed that knowledge of HIV risk factors does not always translate into practicing preventative behaviors to reduce the risk of acquiring or transmitting HIV infection. Therefore, effective theoretical frameworks such as Bandura's social learning theory, ${ }^{39}$ theory of reasoned action, ${ }^{40}$ theory of planned behavior, ${ }^{40}$ and the health belief model $(\mathrm{HBM})^{41}$ are needed to create effective public health education strategies that can help translate HIV knowledge into HIV preventative behaviors. In a study in which Reinecke and colleagues evaluated the effect of the theory of planned behavior in influencing condom use with a new sexual partner among 650 German youths, they found that beliefs, attitudes, and intentions concerning condom use changed over a relatively short period after this theory was employed. ${ }^{42}$ They explained that an effective intervention in HIV prevention would not only have to persuade young people of the attractiveness of the behavior (use of condoms) but also provide skills and the means to perform the behavior. In addition, a recent literature review showed that the constructs of the HBM (perceived susceptibility to HIV/AIDS, perceived severity of HIV/AIDS, perceived ben- efit of condom use, perceived barriers to condom use, cues to action for condom use and condom use self-efficacy) are the most commonly used theory components in health education, health promotion and disease prevention. ${ }^{43}$ By employing both the HBM and theory of planned behaviors in influencing condom use, behavioral change in condom use may be obtained and sustained. ${ }^{44}$

\section{LIMITATIONS}

One of the major limitations of this analysis is that the survey was based on the self-report of sexual and other related behaviors. Previous studies have shown that women tend to underreport and men tend to exaggerate their premarital and extramarital sexual activity. ${ }^{45}$ Some of the findings for this analysis may be biased because some women and men may not correctly report their number of sexual partners, use of condoms, and other related risk behaviors. Another limitation is that the cross-sectional nature of the survey does not allow for the determination of a temporal relationship between the explored variables and HIV infection. Besides these limitations, this study provides a better understanding of the current prevalence and the associated factors of HIV among women and men in Ghana. The 
Table 3. Bivariate analysis to assess the unadjusted association of the socio-demographic, HIV-related behaviors and knowledge of HIV prevention

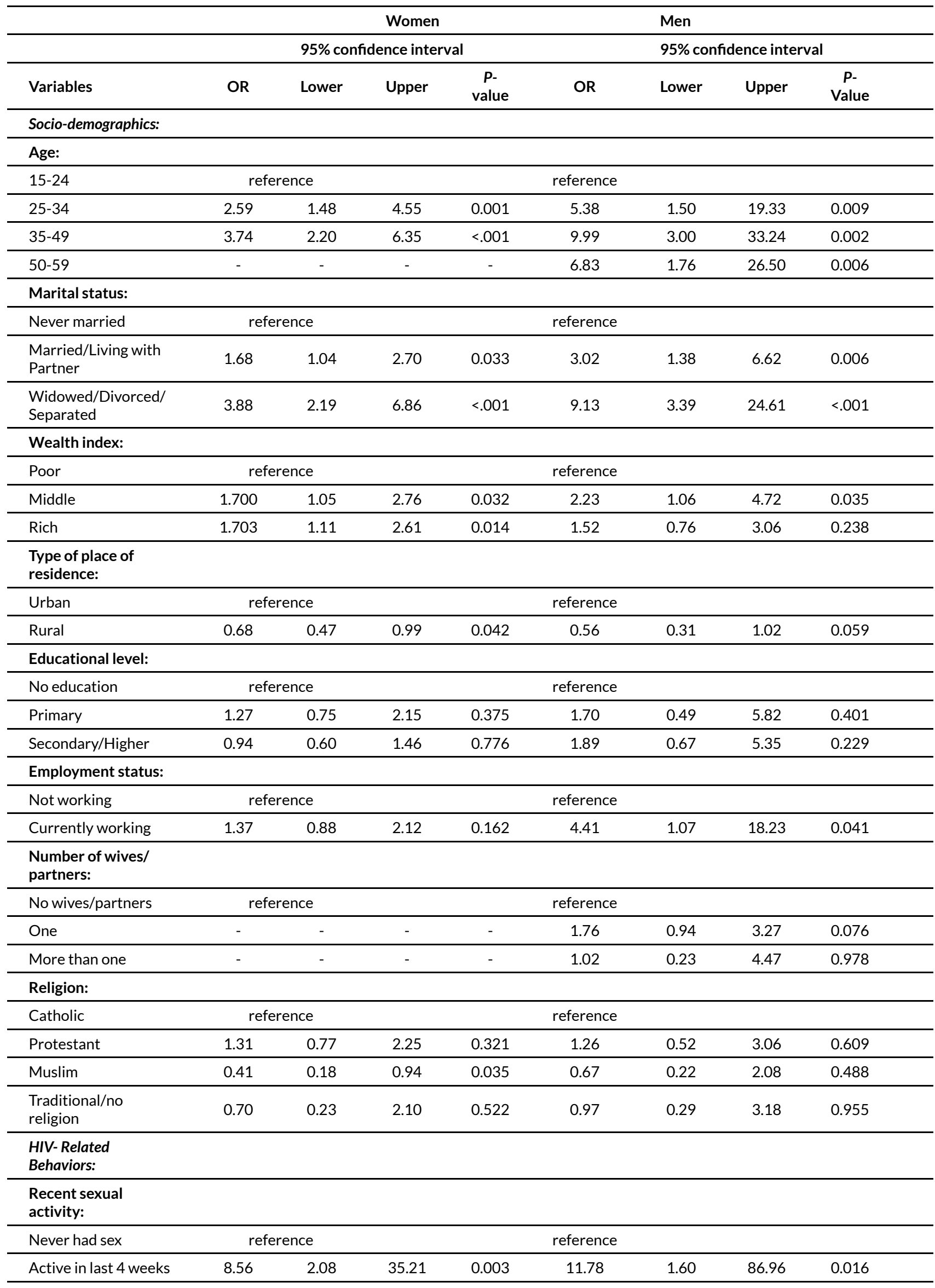




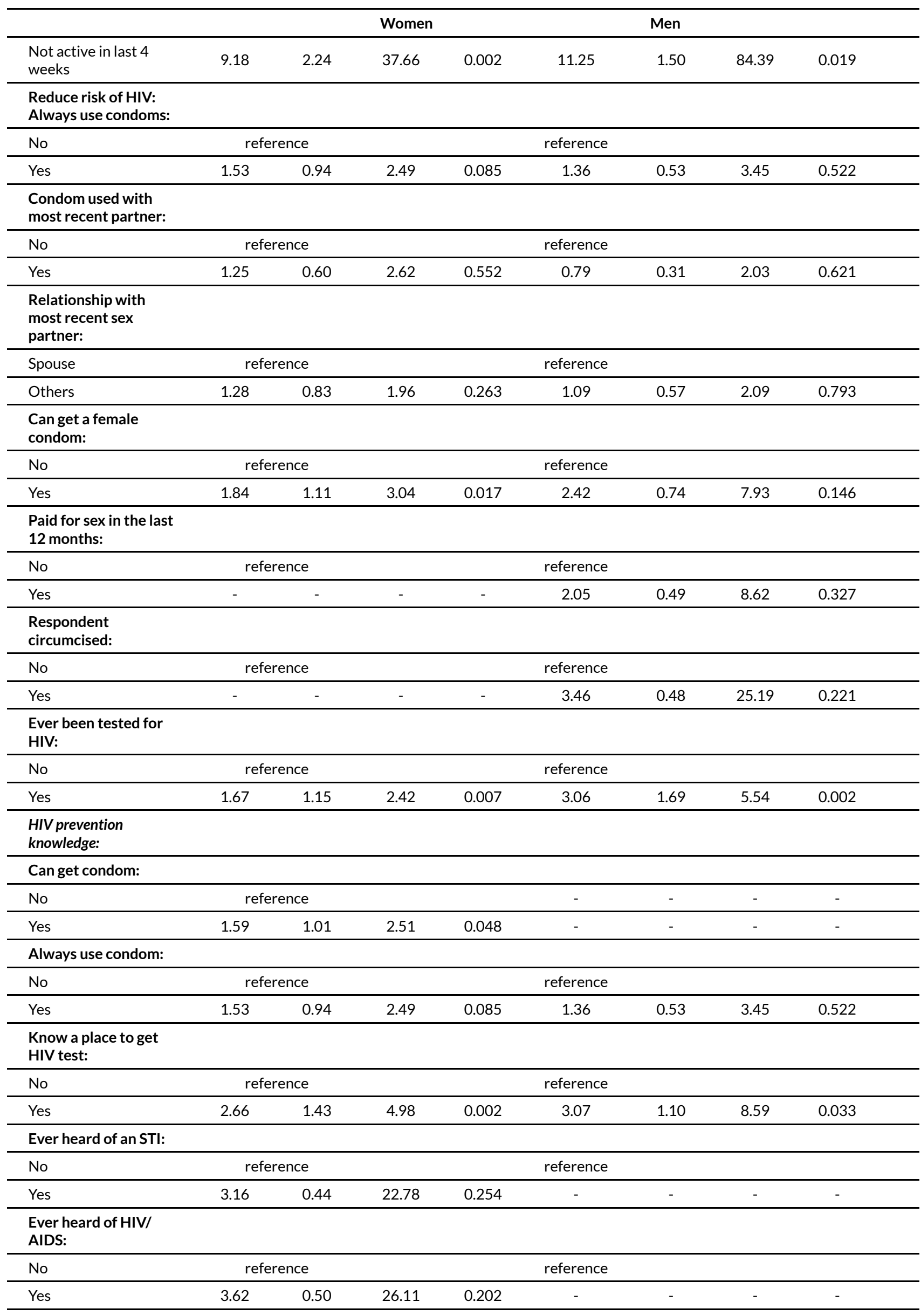




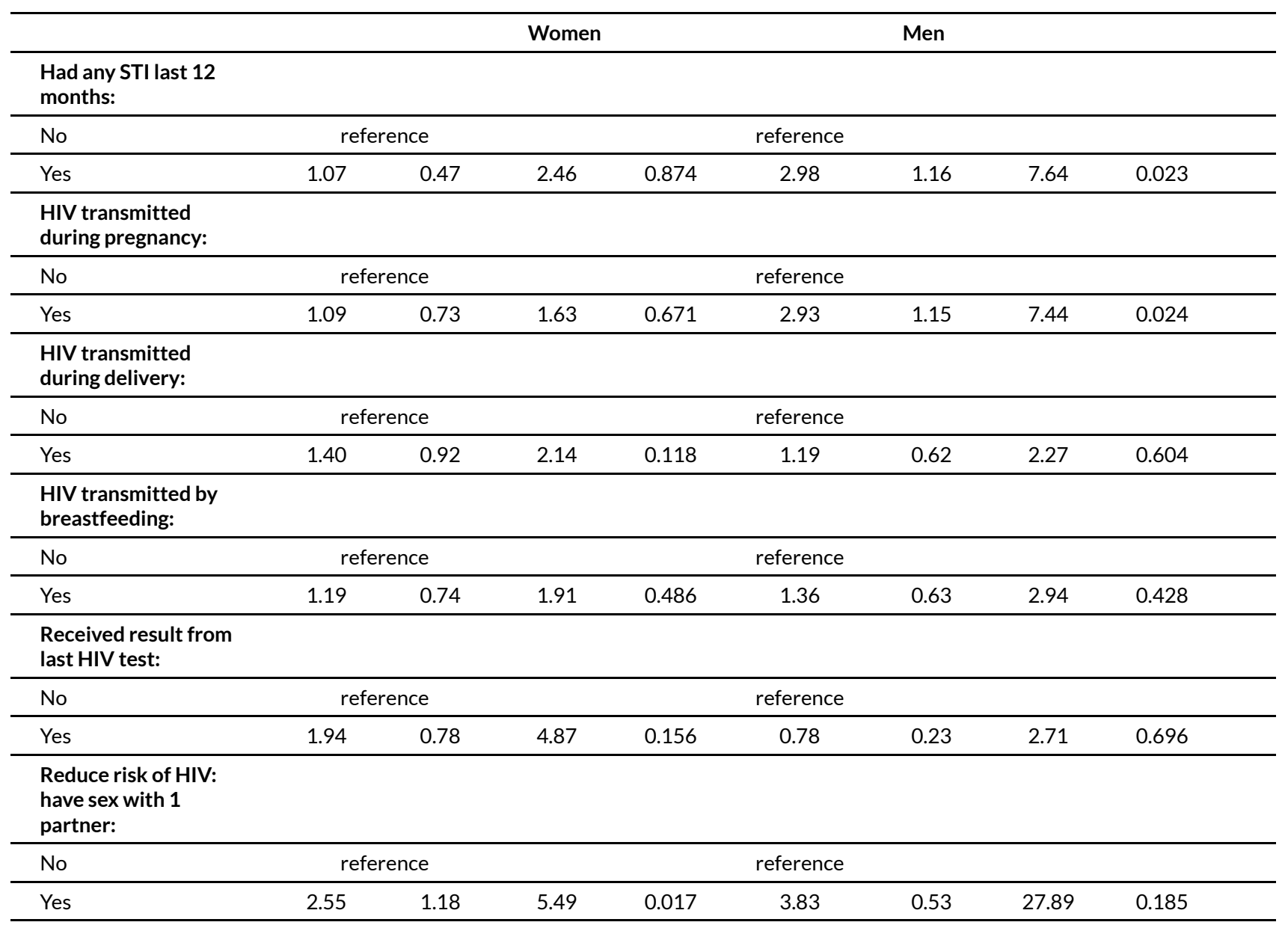

OR - odds ratio, STI - sexually transmitted infection, - not applicable

Note: HIV transmitted during pregnancy, HIV transmitted during delivery, and HIV transmitted by breastfeeding are participants

knowledge about these methods of HIV transmission.

findings are significant in identifying factors related to the prevalence of HIV infection in Ghana, which can be used to better tailor HIV prevention and intervention strategies at the national, regional, and individual levels.

\section{CONCLUSION}

This study documents the current prevalence and related factors of HIV infection in Ghana. The findings are useful in identifying high-risk populations and strengthening prevention and treatment programs. HIV control and prevention programs should target all levels of the social-ecological model (policy, community, organization, interpersonal, and individual) in order to be successful at reducing the risk factors associated with HIV in Ghana. Further investigation is needed to determine the temporal relationship between risk factors and HIV infection to determine effective intervention strategies for reducing the burden of HIV in Ghana.

\section{ACKNOWLEDGEMENTS}

The authors thank the DHS program implemented by ICF for their support and for free access to the original data.
FUNDING

This work was not supported by any external or internal funding.।

\section{COMPETING INTERESTS}

The authors completed the Unified Competing Interest form at http://www.icmje.org/coi_disclosure.pdf (available upon request from the corresponding author), and declare no conflicts of interest.।

\section{CORRESPONDENCE TO:}

Djibril M. Ba, MPH

Research Data Management Specialist Department of Public Health Sciences Penn State College of Medicine

90 Hope Drive

Suite 2200, MC A21

Hershey, PA 17033

USA

djibrilba@phs.psu.edu 
Table 4. Multivariable logistic regression results

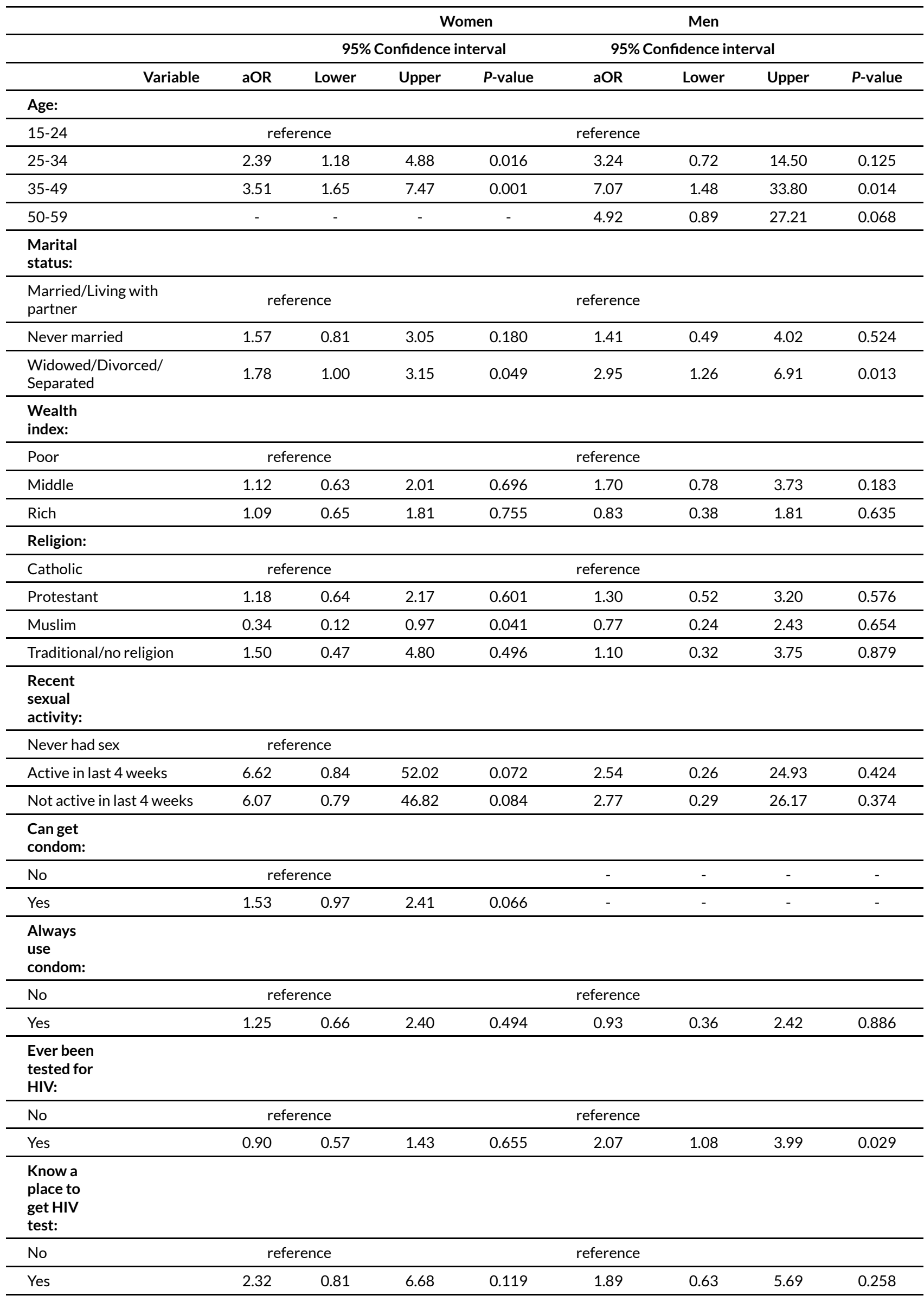




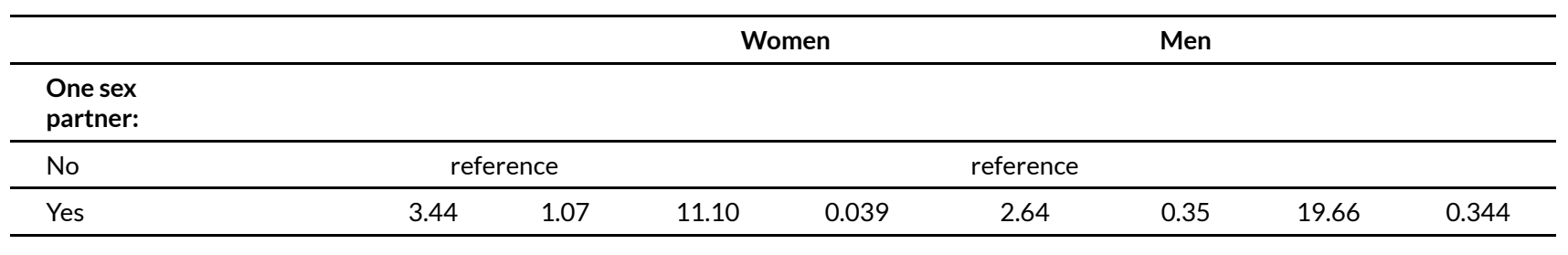

aOR - adjusted odds ratio, - not applicable 


\section{REFERENCES}

1. UNAIDS. Fact Sheet-Latest Statistics on the Status of the AIDS Epidemic 2017, Global Statistics. UNAIDS; 2017. Accessed October 15, 2019. https://www.unaid s.org/en/resources/fact-sheet

2. UNAIDS. Ghana. Published online 2018. Accessed November 30, 2019. https://www.unaids.org/en/regio nscountries/countries/ghana

3. Addo N, Yawson A, Addo A, Dornoo B, Seneadza H. A Review of National Programme Data on the HIV Epidemic in Ghana: 2005-2010. Posgraduate Med J Ghana. 2014;3:7381.

4. Anarfi J. Universities and HIV/AIDS in Sub Saharan Africa: A Case Study of the University of Ghana, Legon. ADEA Working Group in Higher Education; 2000.

5. Royce RA, Seña A, Cates W Jr, Cohen MS. Sexual transmission of HIV. N Engl J Med. 1997;336(15):1072-1078. doi:10.1056/neim199704103 $\underline{361507}$

6. Commission GA. Ghana HIV/AIDS Strategic Framework, 2001-2005: Ghana AIDS Commission. Published online 2001. Accessed June 20, 2017. http s://www.ilo.org/aids/legislation/WCMS 126717/langen/index.htm

7. Ghana AIDS Commission. Ministry of Health, NACP: Republic of Ghana National HIV and, STI Policy. Ghana AIDS Commission; 2013. Accessed June 21, 2017. http s://www.healthpolicyproject.com/pubs/153 Policyfina $\underline{1 . p d f}$

8. Ghana Demographic and Health Survey 2014. GSS, GHS, and ICF International Accessed June 21, 2017. ht tps://dhsprogram.com/pubs/pdf/FR307/FR307.pdf.Acc essed:

9. Demographic Health Survey Sampling and Household Listing Manual. Measure DHS; 2012. Accessed June 21, 2017. https://dhsprogram.com/pubs/pdf/DHSM4/DHS 6 Sampling_Manual_Sept2012_DHSM4.pdf

10. The Demographic and Health Surveys Program. Accessed November 24, 2019. https://dhsprogram.co $\mathrm{m}$ /topics/HIV-Corner/HIV-Prevalence-and-HIV-Testi ng.cfm

11. Mishra V, Vaessen M, Boerma J, Arnold F, Way A, Barrere B. HIV testing in national population-based surveys: experience from the Demographic and Health Surveys. Bull World Health Organ. 2006;84(07):537-545. doi:10.2471/blt.05.029520
12. Macro International Inc. Measure DHS: demographic and healthsurveys. Accessed May 13, 2019. https://dhsprogram.com/What-We-Do/Questio nnaires.cfm

13. Lunani LL, Abaasa A, Omosa-Manyonyi G. Prevalence and factors associated with contraceptive use among Kenyan women aged 15-49 years. AIDS Behav. 2018;22(S1):125-130. doi:10.1007/s10461-01 8-2203-5

14. Titilayo A, Palamuleni ME, Olaoye-Oyesola JO, Owoeye OM. Religious Perceptions and attitudes of men towards discontinuation of female genital cutting in Nigeria: evidence from the 2013 Nigeria Demographic and Health Survey. Afr J Reprod Health. 2018;22:20-28.

15. Ba DM, Ssentongo P, Agbese E, Kjerulff KH. Prevalence and predictors of contraceptive use among women of reproductive age in 17 sub-Saharan African countries: A large population-based study. Sex Reprod Healthc. 2019;21:26-32. doi:10.1016/j.srhc.2019.06.00 $\underline{2}$

16. Maiga M. Gender, AIDS and Food Security: Culture and Vulnerability in Rural Côte d'Ivoire. Wageningen Academic Publishers; 2010. doi:10.3920/978-90-868 $\underline{6-715-8}$

17. Negin J, Cumming RG. HIV infection in older adults in sub-Saharan Africa: extrapolating prevalence from existing data. Bull World Health Organ. 2010;88(11):847-853. doi:10.2471/blt.10.07634 $\underline{9}$

18. Carpenter LM, Kamali A, Ruberantwari A, Malamba SS, Whitworth JAG. Rates of HIV-1 transmission within marriage in rural Uganda in relation to the HIV sero-status of the partners. AIDS. 1999;13(9):1083-1089. doi:10.1097/00002030-199906 180-00012

19. Floyd S, Crampin AC, Glynn JR, et al. The longterm social and economic impact of HIV on the spouses of infected individuals in northern Malawi. Trop Med Int Health. 2008;13(4):520-531. doi:10.1111/ j.1365-3156.2008.02030.x

20. Lopman BA, Nyamukapa C, Hallett TB, et al. Role of widows in the heterosexual transmission of HIV in Manicaland, Zimbabwe, 1998-2003. Sex Transm Infect. 2009;85(Suppl 1):i41-i48. doi:10.1136/sti.2008.03304 $\underline{3}$ 
21. Mackelprang RD, Bosire R, Guthrie BL, et al. High rates of relationship dissolution among heterosexual HIV-serodiscordant couples in Kenya. AIDS Behav. 2014;18:189-193. doi:10.1007/s10461-013-0529-6

22. Porter L, Hao L, Bishai D, et al. HIV status and union dissolution in sub-Saharan Africa: the case of Rakai, Uganda. Demography. 2004;41(3):465-482. do i:10.1353/dem.2004.0025

23. Shisana O, Rehle T, Simbayi LC, Zuma K, Jooste S, Zungu N, et al. South African National HIV Prevalence, Incidence and Behaviour Survey, 2012. HSRC Press; 2014.

24. Maharaj P, Cleland J. Risk perception and condom use among married or cohabiting couples in KwaZuluNatal, South Africa. Int Fam Plan Perspect. 2005;31(01):24-29. doi:10.1363/3102405

25. Shandera WX. Key determinants of AIDS impact in Southern sub-Saharan Africa. Afr J AIDS Res. 2007;6(3):271-286. doi:10.2989/16085900709490423

26. Chemaitelly H, Cremin I, Shelton J, Hallett TB, Abu-Raddad LJ. Distinct HIV discordancy patterns by epidemic size in stable sexual partnerships in subSaharan Africa. Sex Transm Infect. 2012;88:51-57. do i:10.1136/sextrans-2011-050114

27. Dunkle KL, Stephenson R, Karita E, et al. New heterosexually transmitted HIV infections in married or cohabiting couples in urban Zambia and Rwanda: an analysis of survey and clinical data. Lancet. 2008;371(9631):2183-2191. doi:10.1016/s0140-6736(0 8)60953-8

28. de Walque D. Sero-discordant couples in five African countries: Implications for prevention strategies. Popul Dev Rev. 2007;33(3):501-523. doi:1 0.1111/j.1728-4457.2007.00182.x

29. Msisha WM, Kapiga SH, Earls F, Subramanian S. Socioeconomic status and HIV seroprevalence in Tanzania: a counterintuitive relationship. Int J Epidemiol. 2008;37(6):1297-1303. doi:10.1093/ije/dyn $\underline{186}$

30. Napierala Mavedzenge S, Olson R, Doyle AM, Changalucha J, Ross DA. The Epidemiology of HIV Among Young People in Sub-Saharan Africa: Know Your Local Epidemic and Its Implications for Prevention. J Adolesc Health. 2011;49(6):559-567. do i:10.1016/j.jadohealth.2011.02.012

31. Mishra V, Bignami S, Greener R, Vaessen M, Hong $\mathrm{R}$, Ghys P, et al. A study of the association of HIV infection with wealth in sub-Saharan Africa. Published online 2007. Accessed June 21, 2017. http s://pdfs.semanticscholar.org/2210/867599f8d2fadc1fa 7c633e5ca5de7b1c020.pdf
32. Parkhurst JO. Understanding the correlations between wealth, poverty and human immunodeficiency virus infection in African countries. Bull World Health Organ. 2010;88(7):519-526. doi:10.2471/blt.09.070185

33. Igulot P, Magadi MA. Socioeconomic status and vulnerability to HIV infection in Uganda: Evidence from multilevel modelling of AIDS Indicator Survey Data. AIDS Res Treat. 2018;2018:7812146. doi:10.115 $\underline{5 / 2018 / 7812146}$

34. Shelton JD, Cassell MM, Adetunji J. Is poverty or wealth at the root of HIV? Lancet. 2005;366:1057-1058. doi:10.1016/s0140-6736(05)674 $\underline{01-6}$

35. Takyi BK. Religion and women's health in Ghana: Insights into HIV/AIDs preventive and protective behavior. Soc Sci Med. 2003;56(6):1221-1234. doi:10.1 016/s0277-9536(02)00122-3

36. Gray PB. HIV and Islam: is HIV prevalence lower among Muslims? Soc Sci Med. 2004;58(9):1751-1756. doi:10.1016/s0277-9536(03)00367-8

37. Dyson T. HIV/AIDS and urbanization. Popul Dev Rev. 2003;29(3):427-442. doi:10.1111/j.1728-4457.200 3.00427.x

38. Moore AM, Biddlecom AE, Zulu EM. Prevalence and meanings of exchange of money or gifts for sex in unmarried adolescent sexual relationships in subSaharan Africa. Afr J Reprod Health. 2007;11(3):44. do $\mathrm{i}: 10.2307 / 25549731$

39. Bandura A. Social-learning theory of identificatory processes. Handbook of Socialization Theory and Research. 1969;213:262.

40. Montano DE, Kasprzyk D. Theory of reasoned action, theory of planned behavior, and the integrated behavioral model. Health Behavior: Theory, Research and Practice. 2015:95-124.

41. Rosenstock IM, Strecher VJ, Becker MH. The Health Belief Model and HIV Risk Behavior Change. In: DiClemente RJ, Peterson JL, eds. Preventing AIDS. Springer; 1994:5-24. doi:10.1007/978-1-4899-119 3-32

42. Reinecke J, Schmidt P, Ajzen I. Application of the Theory of Planned Behavior to Adolescents' Condom Use: A Panel Study 1. J Appl Social Pyschol. 1996;26(9):749-772. doi:10.1111/j.1559-1816.1996.tb $\underline{01128 . x}$

43. Tarkang EE, Zotor F. Application of the Health Belief Model (HBM) in HIV prevention: a literature review. Central African Journal of Public Health. 2015;1:1-8. 
44. Montanaro EA, Bryan AD. Comparing theorybased condom interventions: health belief model versus theory of planned behavior. Health Psychol. 2014;33(10):1251-1260. doi:10.1037/a0033969
45. Zaba B, Boerma J, Pisani E, Baptiste N, eds. Estimation of levels and trends in age at first sex from African demographic surveys using survival analysis. In: Annual Meeting of the Population Association of America, Atlanta. ; 2002. 